\title{
Factors Relating to Managerial Stereotypes: The Role of Gender of the Employee and the Manager and Management Gender Ratio
}

\author{
Janka I. Stoker • Mandy Van der Velde • \\ Joris Lammers
}

Published online: 19 March 2011

(c) The Author(s) 2011. This article is published with open access at Springerlink.com

\begin{abstract}
Purpose Several studies have shown that the traditional stereotype of a "good" manager being masculine and male still exists. The recent changes in the proportion of women and female managers in organizations could affect these two managerial stereotypes, leading to a stronger preference for feminine characteristics and female leaders. This study examines if the gender of an employee, the gender of the manager, and the management gender ratio in an organization are related to employees' managerial stereotypes. Design/Methodology/Approach 3229 respondents working in various organizations completed an electronic questionnaire.

Findings The results confirm our hypotheses that, although the general stereotype of a manager is masculine and although most prefer a man as a manager, female employees, employees with a female manager, and employees working in an organization with a high percentage of female managers, have a stronger preference for feminine characteristics of managers and for female managers. Moreover, we find that proximal variables are much stronger predictors of these preferences than more distal variables.
\end{abstract}

\section{J. I. Stoker ( $\square)$}

Faculty of Economics and Business, University of Groningen, P.O. Box 800, 9700 AV Groningen, The Netherlands e-mail: j.i.stoker@rug.nl

\section{Van der Velde}

University of Utrecht, Utrecht, The Netherlands

J. Lammers

University of Tilburg, Tilburg, The Netherlands
Implications Our study suggests that managerial stereotypes could change as a result of personal experiences and changes in the organizational context. The results imply that increasing the proportion of female managers is an effective way to overcome managerial stereotyping.

Originality/Value This study examines the influence on managerial stereotypes of various proximal and distal factors derived from theory among a large group of employees (in contrast to students).

Keywords Leadership · Gender ·

Managerial stereotypes - Management gender ratio

\section{Introduction}

Over the past decades, there has been a significant increase in the number of female managers (Ayman et al. 2009). This increase has coincided with a shift in thinking on effective leadership as described by Yukl (2002), who claims that women are more skilled at interpersonal relationships and are, therefore, superior managers in present society (the so-called Feminine advantage).

However, women are still underrepresented at senior levels of the management hierarchy (European Board Women Monitor 2004) and in other management positions (for an overview, see Schein 2001). In 2009, the number of organizations with only men in the board even increased. The Female FTSE Indicator stresses a "discouraging decline" in the number of companies with female executive directors and a decline in the number of boards with multiple women directors (Sealy et al. 2009, p. 6).

One of the explanations for this situation can be found in role congruity theory (Eagly 1987), which states that there is incongruence between the female gender role and 
the manager role. Because of sexist stereotypes, women are expected to engender characteristics like warmth, modesty, and sensitivity. These expectations cause disadvantages for female managers, because they are inconsistent with the stereotype that people have of leaders; leaders are supposed to be strong, result-oriented, and willing to take risks. As a result, women face prejudicial evaluation of their competence as managers (Eagly and Carli 2003b), leading to a decreased access to leadership roles (Eagly and Karau 2002) and more negative evaluations (Brescoll et al. 2010).

Research suggests that these stereotypes are not changing over time. Powell et al. (2002) and Powell and Butterfield $(1979,1989)$ studied managerial stereotypes among students for over three decades. Respondents were asked to describe good managers by rating the importance of a number of personality traits. The results found in 2002 were not much different from the results found in 1979 and 1989. Students defined good leadership with masculine characteristics and believed that female traits were irrelevant or even harmful for good leadership (Powell et al. 2002). However, the studies were based on the perceptions of students, which may not be representative of perceptions of employees (Sczesny 2003; Sczesny et al. 2004). Furthermore, changes in the proportion of women in organizations as well as changes in thinking about effective leadership (Yukl 2002) could affect both gender stereotypes (i.e., what makes a good woman) and managerial stereotypes (i.e., what makes a good manager) (Eagly and Sczesny 2009).

Because the gender-composition in organizations has changed dramatically in the last decades, this change could have affected managerial stereotypes. Therefore, in this study, we examine preferences of employees for masculine and feminine leadership characteristics, and for having a male or a female manager. More specifically, we focus on three factors related to gender that could affect these preferences for feminine characteristics. These factors are: the gender of the employee, the gender of the manager, and the management gender ratio in the organization (Duehr and Bono 2006; Schein 2001; Sczesny et al. 2004; Vecchio and Boatwright 2002). We also propose that the magnitude of the effect of these factors will differ: we expect that the two proximal variables, gender of the employee, and gender of the manager, will have a stronger effect than the more distal variable, gender management ratio. Finally, we will explore possible interactions between the factors and the preferences for feminine characteristics.

These findings will add empirical knowledge to the theoretical debate on the perseverance of managerial stereotypes and will also offer suggestions on the ways to deal with managerial stereotypes in organizational practice.

\section{Theoretical Background}

\section{Gender Stereotypes and Managerial Stereotypes}

Based on social role theory (Eagly 1987; Eagly et al. 2000), Eagly and Carli (2003a, b) claim that female managers suffer disadvantages based on prejudices related to gender and managerial stereotypes: a "good" woman is sensitive and caring, and that is not what generally is expected from good managers. For female managers there is a clear incongruity between their gender role and the managerial role (Eagly and Carli 2007; Stuhlmacher and Poitras 2010). This incongruity leads to negative evaluations of female managers (Johnson et al. 2008). And, according to the opinion of $72 \%$ CEOs (male and female) and $51 \%$ female executives (Wellington et al. 2003), these negative attitudes limit the access of women to managerial positions (see also Eagly 2007; Lyness and Heilman 2006).

However, if these stereotypes of the gender role and/or the managerial role change, the role incongruity for female leaders might disappear. Gender stereotypes indeed seem to have changed over the last years, due to changes in the social roles of men and women in society (Eagly and Sczesny 2009). This change primarily affected the gender role of women, who have acquired more masculine characteristics, while keeping the feminine characteristics (Diekman and Goodfriend 2006). The gender role of men did not change (Eagly and Sczesny 2009).

In this article, we focus on changes in managerial stereotypes. There are two related, yet different categories of managerial stereotypes. The first is the "think managerthink male" stereotype (Schein, 1973, 1975), associating being a manager with being a man (e.g., Heilman et al. 1995; Ryan and Haslam 2007; Willemsen 2002; for an overview see Eagly 2007). The other stereotype is the "think manager-think masculine" association (Powell et al. 2002). Masculine leadership, also called "agentic" leadership (Eagly and Karau 2002) is defined by a willingness to take risks and being task-oriented. Conversely, feminine leadership, also called "communal" leadership (Eagly and Karau 2002), is considered more nurturing, helpful, and people-oriented. This stereotyping implies that masculinity, regardless of sex, is associated with good leadership (see also Billing and Alvesson 2000). This stereotype has been found to continue to exist over the years (see Powell and Butterfield 1979, 1989; Powell et al. 2002).

However, because women entered the work force during the last couple of decades, including entering into managerial-level positions, managerial stereotypes could change. We argue that this shift in stereotypes is connected to three gender-related variables in the organization: the gender of the employee, the gender of the current manager, and management gender ratio. 
Gender of the Employee

Several authors argue that the employees' gender (see e.g., Vecchio and Boatwright 2002) is relevant for leadership stereotypes. According to this view, women tend to have a stronger preference for (or lower aversion against) female characteristics and for female leaders. This could be caused by the similarity attraction effect (Byrne 1971). People like people who are similar to themselves. Hence, women like leaders who have the same gender and share certain characteristics. More specifically, research by Ayman et al. (2009) has shown strong gender differences in leadership schemas. Although generally the cognitive schema or stereotype for a manager is composed of masculine traits ("think manager-think masculine" stereotype, Powell et al. 2002), this schema appears to be more masculine among boys and men than among girls and women (AymanNolley and Ayman 2005; Deal and Stevenson 1998; Schein 2001; Sczesny 2003). This is consistent with social identity theory (Tajfel and Turner 1986); the tendency among men to see masculine leadership traits as important can be a reflection of their in-group bias-men like male traits because they define and retain their own social group.

Although studies among students did not show significant differences in leadership stereotypes of men and women (Powell et al. 2002), Schein (2001) found strong evidence that female employees no longer sex-type the managerial position. Brenner et al. (1989) also found that women described successful middle managers as having both stereotypically masculine and feminine characteristics, whereas there seems to be a strong tendency for male respondents to stick to the managerial stereotype. This does not mean that women do not like male or masculine leadership as such; they only seem to appreciate feminine characteristics or a combination of feminine and masculine characteristics more than men do. In sum, we predict that:

Hypothesis 1 Female employees more strongly prefer feminine leadership characteristics than do male employees; there are no differences for masculine leadership characteristics.

Hypothesis 2 Female employees have a less strong preference for male managers than do male employees.

\section{Gender of the Manager}

The second factor in this study is the gender of the current manager. In the presence of substantial amounts of disconfirming information, the schemas that people may have about certain social groups can be changed and thus become less affected by stereotypes. That is, if people have certain schemas about members of a certain group ("women are like this"), once they meet someone who disconfirms this schema, this can lead to a revision of one's schema ("women are not necessary like this, they can also be like that") (Amir 1969; Brewer and Miller 1988; Rothbart 1981; Rothbart and John 1985). Most of this research into the effect of stereotype disconfirmation has been conducted on racial relations, national relations, and age relations (see e.g., Jackson and Sullivan 1988)—but not on gender. Nonetheless, a successful female manager should also have the potential to change the leadership stereotype of workers, by showing that feminine traits and leadership can go hand in hand. Research shows that moderately inconsistent information is more effective in reducing stereotypes than extremely inconsistent information (Tausch and Hewstone 2010). The changing role of women in organizations in general (Diekman et al. 2005; Diekman and Eagly 2000), and more specifically the experience of having a female manager, can be considered as disconfirming information. The managerial stereotypebeing masculine and being a man, may become less logical if an employee deals with a female manager in daily work.

With respect to earlier findings, it is not certain that having a female manager will actually lead to changes in stereotypes. Hughes and Seta (2003) argue that “... even though men and women are crossing the boundaries of gender stereotypes and are taking on increasingly androgynous roles, traditional gender-role stereotypes persist in the face of disconfirming information." (p. 686). There even seems to be a difference for males and females. Past research namely shows that women who show masculine behavior are not perceived as inconsistent, whereas men who demonstrate feminine behaviors are regarded as very inconsistent. So female managers are permitted to be more flexible in their behavior (Hughes and Seta 2003). This could imply that the experiences of employees with female managers offer moderately but acceptable inconsistent information, and therefore could affect the managerial stereotype.

Another theoretical explanation for the effect of the gender of the manager can be found in the Contact Hypothesis (Allport 1954). The idea is that increased contact between members of two groups (e.g., men and women), where the two groups work toward a shared goal (to increase production or meet other goals of their organization), and do so in an informal setting that does not necessarily reinforce existing stereotypes, can strongly decrease negative stereotyping and can increase the attitudes that members of the groups have of each other (Sherif et al. 1961). Ample research has validated this idea (e.g., Jones 1997; Pettigrew 1997). Following this line of reasoning, Powell (1993) proposed that managerial stereotypes should theoretically disappear once employees become familiar with female managers as individuals rather than as representatives of their gender. 
Indeed, Lortie-Lussier and Rinfret (2002) conclude that attitudes toward female managers are more favorable among respondents who have been supervised by a woman (see also Duehr and Bono 2006). One of the problems of this empirical finding is that it mainly concerns the evaluation of women, and not of managerial stereotypes. Based on the previous argumentation, we expect that the increase in preference for feminine characteristics should not necessarily come at the cost of a decrease in preference for masculine characteristics. We therefore expect that:

Hypothesis 3 Employees who currently have a female manager show a stronger preference for feminine leadership characteristics than those with a male manager; there are no such differences for masculine leadership characteristics.

Hypothesis 4 Employees who currently have a female manager show a stronger preference for female managers than those with a male manager.

\section{Management Gender Ratio}

Eagly and Sczesny (2009) argue that stereotypes derive from observations of the representation of group members in professional roles, such as the role of a manager. In this respect, Kanter (1977) proposed tokenism theory. When only a few managers are female (less than 15-20\%), they can be considered as "tokens." Tokens face three negative experiences (Kanter 1977; King et al. 2010; Young and James 2001). First, tokens are very visible, which leads to increased performance pressure. Second, there are exaggerated differences between women (tokens) and men (dominants), leading to feelings of isolation among tokens, since they cannot connect either to the dominant group or to the few other tokens (see also Lortie-Lussier and Rinfret 2002). Third, tokens experience expectations with respect to role behavior that is consistent with their gender stereotype. As Swan and Wyer (1997) note, when individuals are in the minority in a social context, their sex is principally salient. Based on this heightened salience, their behavior is more likely to be interpreted in terms of gender stereotypes (Swan and Wyer 1997).

Empirical research shows mixed support for tokenism theory. Indeed, there are studies confirming that numerical representation is negatively correlated with discrimination (see for an overview King et al. 2010). However, there is also evidence that some tokens do not face the problems as described above (see e.g., Sackett et al. 1991). According to Yoder and Schleicher (1996), this is related to the degree of traditionalism of the occupation. With respect to the occupation of manager, the stereotypical association between manager and masculinity or men is clear, making management a male domain. Moreover, research shows that women, who are the minority in a male domain such as management, are indeed likely to experience the greatest prejudice and discrimination (see King et al. 2010; Voci et al. 2008).

With respect to the changes in organizations in the gender management ratio, it can be argued that the distinction between the tokens (minority) and the dominants (majority) fades away. Female managers are therefore no longer seen as tokens: consequently, a manager can simply be either a man or a woman. As a result, one could assume that women's competences and status will be increasingly appreciated as their proportion increases. This would imply that the raise in the percentage of women in leadership roles has an effect on the stereotype of women and leaders, bringing them closer together (Eagly and Sczesny 2009). Ely (1995) indeed found significant differences in the views of women, depending on the percentages of women in senior positions in their organization. Results suggest that gender roles are more stereotypical and more problematic in organizations with relatively few senior women.

This might also have an effect on the two managerial stereotypes. Being exposed to information or behavior that is inconsistent to the managerial stereotype might change this stereotype. Results from experimental studies confirm that stereotypes can be undermined by presenting information that is inconsistent with the stereotype (Asuncion and Mackie 1996; Tausch and Hewstone 2010). Therefore, based on Powell et al. (2002), we formulated the following hypotheses:

Hypothesis 5 An increase in the proportion of women in management positions predicts a stronger preference for feminine leadership characteristics; there are no such differences for masculine leadership characteristics.

Hypothesis 6 An increase in the proportion of women in management positions predicts an increased preference for female managers.

\section{Relative Effects of the Factors and Their Interactions}

We expect that these three factors (gender of the employee, management gender, and management gender ratio) will differ with respect to their relative effects. In particular, we expect that the more proximal (or close) variables of gender of the employee and gender of manager will have a stronger effect than the more distal variable, management gender ratio. This prediction is well-founded in various theories of manager-employee relations, such as LMX-theory, which stresses the uniquely strong bond between managers and their direct 
subordinates (Liden et al. 1997). More generally, employees will be more likely to see their direct manager (who is psychologically close) as a "significant other" than that they will be likely to see other managers in their company as such (Cooley 1909; Mead 1962). As "significant others" strongly influence people's view of the world-including, we predict, their perspectives on gender and management-we expect that respondents' own gender and the gender of their direct manager will have a stronger effect on their perspectives on masculinity, femininity, and management, than will management gender ratio. Based on these assumptions, we formulate the following hypothesis:

Hypothesis 7 Gender of the employee and gender of the manager will have a stronger effect on the preference for feminine leadership characteristics than will gender management ratio.

Finally, we explore possible interactions among the three factors. For example, we could find effects of the so-called dyad gender composition between gender of the employee and gender of the manager (Ayman et al. 2009). Eagly et al. (1992) found that men evaluated women more negatively than men (Duehr and Bono 2006; McCollKennedy and Anderson 2005; Atwater et al. 2004), whereas women rated both sexes more equally. A study by Ayman et al. (2009) on the effects of transformational leadership showed that evaluations of male subordinates were less positive for female managers than those of female subordinates for female managers.

Although these interactions all relate to evaluations of male and female managers by male and female employees, and not to masculinity and femininity in managerial stereotypes, comparable effects might occur with respect to a preference for feminine leadership characteristics. That is, female employees with female managers might have a stronger preference for feminine characteristics than male employees with female managers.

Related to this, there might be an interaction between gender management ratio and gender of the employee. In line with tokenism theory (Kanter 1977), it could be argued that in situations with a low percentage of female managers, especially male employees have a more masculine schema than female employees (Ayman-Nolley and Ayman 2005; Deal and Stevenson 1998; Schein 2001; Sczesny 2003). After all, in such situations with no or only few female managers, it is relatively easy to hold biased, sexist leadership beliefs. In such situations, there is no pressure from the organizational culture to update or modernize one's beliefs. Given that we especially expect men to hold such beliefs (compared to women), it seems likely that men will also be more strongly affected if the percentage of female managers increases.

\section{Method}

\section{Respondents}

The respondents were 3,229 subscribers to the weekly Dutch journal, Intermediair, which is aimed at employed people with senior professional qualifications and/or a university degree. Participation was voluntary and anonymous. In our sample, $67 \%$ of the respondents were men, and the average age of all the respondents was 36 $(\mathrm{SD}=6.2)$, ranging between 25 and 45 , because this age group can receive Intermediair free-of-charge. As with any professional sample, the educational level of participants was high, with half having a vocational degree and half a university degree. Overall, $60 \%$ of the sample worked in a for-profit organization and $40 \%$ in a not-for-profit organization, with $22 \%$ in industry, $18 \%$ in service organizations, $14 \%$ working for the government, $13 \%$ in health and education, $9 \%$ worked for financial service providers, $6 \%$ in transport, $5 \%$ in the ICT sector, and $13 \%$ working in other lines of business. $4 \%$ of the respondents described themselves as an entry level, $10 \%$ as junior, $38 \%$ as midlevel, $41 \%$ as seniors, and $7 \%$ as very senior. $80 \%$ of our respondents had a male manager and $14 \%$ had a female manager. The remaining $6 \%$ did not have a manager, being either entrepreneurs or freelancers without a manager. These 200 respondents were, therefore, deleted from the analyses.

\section{Measurement Instruments}

We sent the respondents an electronic questionnaire in Dutch based on scale items originally formulated in English. We used the technique of "back translation." The scale items were translated into Dutch by the authors and then, to check that the Dutch terms had the same meaning as the original items in English, we had an English colleague translate them back into English and then we compared his terms with the original expressions. This process resulted in a few minor adjustments. There seemed to be no problem for our Dutch respondents in understanding the questions and the items.

The following initial variables were recorded: gender of the respondent, their age, their educational level, and the gender of their manager. They were then asked about other aspects in more detail.

\section{Management Gender Ratio}

Respondents were asked to indicate the percentage of females in management positions in their organization using five possible categories: 0-20\%, 21-40\%, 41-60\%, 61-80\%, and $81-100 \%$ (based on Kanter 1977). 
Respondents could also indicate the answer "I don't know." In our sample, 111 (3.4\%) of the respondents indicated that they did not know the percentage of female managers in their own organization.

\section{Ideal Leadership Characteristics}

Ideal leadership characteristics were measured using the Short Bem Sex Role Inventory (BSRI, Bem 1981), since earlier research had shown (Campbell et al. 1997) that the short form of the BSRI provided more reliable scores than the long version. We measured 10 items related to masculinity and 10 to femininity, as used by Powell et al. (2002), with two distinct aspects related to each of the 20 items. We asked the respondents: please indicate the degree to which you think an ideal manager should have these characteristics, using an answering scale ranging from $1=$ "not at all" to $5=$ "very much."

Factor analysis and reliability analyses were performed on the results from the Short BSRI. A confirmative factor analysis (using varimax rotation), involving all 20 items, explained $58 \%$ of the total variance in perceived, and $36 \%$ of the total variance in ideal, leadership characteristics. In both the analyses, two factors were extracted. The only real difference to the findings of Powell et al. (2002) concerned the item relating to "aggression." In our study, both in the factor and in the item analyses, this item did not load on the masculinity factor and it also lowered the alpha coefficient of the scale. On the basis of this, the item was deleted from our further analyses. The masculinity scale used in our study thus consisted of nine items: assertive, depends on own beliefs, forceful, has leadership abilities, dominant, strong personality, willing to take risks, independent, and willing to take a stand. The alpha coefficient for this Masculine Leadership Scale was 0.75 . The femininity scale included all the ten items in the Short BSRI: warm, sympathetic, love children, affectionate, eager to soothe hurt feelings, compassionate, understanding, tender, sensitive to the needs of others, and gentle. The alpha coefficient using this scale was 0.81 .

\section{Preference for Male or Female Leader}

We asked respondents whether they preferred a male or a female manager. Respondents had three response options: "male manager," "female manager," or "no preference." This question is based on The Gallup Poll (Simmons 2001; see also Eagly (2007) for an historical overview of The Gallup Poll results). The difference with the original Gallup Poll is that this poll gives no explicit option to answer "no preference," but it could be added if people thought of it for themselves. Please note that we deliberately left this question to the end of the questionnaire to minimize the risk of socially desirable responses.

\section{Results}

\section{Gender of the Employee}

To test Hypothesis 1, we performed a 2 (between: respondent gender) by 2 (within: masculine versus feminine leadership characteristics) mixed-design ANOVA. This analysis resulted in a significant main effect of the within factor of type of characteristics, $F(1,3027)=1990.23, p<.001$, showing that masculine leadership characteristics are generally thought to be more attractive $(M=4.02, S D=0.37)$ than feminine characteristics $(M=3.60, S D=0.44)$, and a main effect of gender, $F(1,3027)=5.99, p=.014$. As predicted, the latter main effect was qualified by an interaction effect, $F(1$, $3027)=5.84, p=.016$. To interpret this interaction effect, we performed two separate ANOVAs for masculine and feminine characteristics. This showed that, as expected, male and female employees do differ in their preference for feminine characteristics. Men find feminine characteristics less attractive $(M=3.58, S D=0.44)$ than women $\operatorname{do}(M=3.63$, $\mathrm{S} D=0.43), F(1,3027)=10.07, p=.002$. As also expected, men $(M=4.02, S D=0.37)$ and women $(M=4.03$, $S D=0.38)$ do not differ in their preference for masculine characteristics, $F(1,3027)=0.28, p=.60$. Hypothesis 1 is therefore confirmed.

In order to test Hypothesis 2, we first inspected the raw data and found $25.2 \%(N=762)$ preferred a male leader, $7.3 \%(N=222)$ preferred a female leader, and $67.5 \%$ $(N=2045)$ indicated no preference. Based on the assumption that a preference for a man reflects a preference against a female leader and vice versa (since there are only two sexes), we analyzed our data by coding a preference for a male leader as -1 , a preference for a female leader as +1 , and no preference as 0 . With this algorithm, we were able to compute the significance of the difference in percentages of preference for male over female leaders, by testing the mean against 0 with a one-sample $t$ test (where a significant negative value represents a preference for male and a positive value a preference for female leaders). These data are shown in Table 1 (top half). We found a strong preference for male leaders, both among male respondents, difference $=$ $-19.1 \%, t(2014)=-15.99, p<.001$, and among female respondents, difference $=-15.3 \%, \quad t(1013)=-8.84$, $p<.001$. Yet a $t$ test comparing this preference for male leaders among male and female respondents showed that this preference is marginally less strong among women than among men, $t(3027)=-1.83, p=.067$. Hypothesis 2 is therefore cautiously confirmed.

\section{Gender of the Manager}

In order to test Hypotheses 3 and 4, we followed the same strategy as in the previous section, but now used gender of 
Table 1 Effect of own gender (top) and gender of manager (bottom) on the preference for male and female managers

\begin{tabular}{llllll}
\hline & Prefer male $(\%)$ & No preference & Prefer female $(\%)$ & Difference & Effect of gender \\
\hline Male respondents $(N=2015)$ & 25.8 & 67.6 & 6.7 & $-19.1 \%, p<.001$ & $t(3027)=-1.83, p=.067$ \\
Female respondents $(N=1014)$ & 24.0 & 67.4 & 8.7 & $-15.3 \%, p<.001$ & \\
Male manager $(N=2583)$ & 26.7 & 67.1 & 6.2 & $-20.4 \%, p<.001$ & $t(3027)=-6.44, p<.001$ \\
Female manager $(N=446)$ & 16.4 & 70.0 & 13.7 & $-2.7 \%, p=.30$ & \\
\hline
\end{tabular}

the manager as independent variable. A 2 (between: manager gender) by 2 (within: masculine versus feminine leadership characteristics) mixed-design ANOVA showed a significant main effect of the within factor of type of characteristics, $F(1,3027)=993.30, p<.001$. It showed that masculine leadership characteristics are generally thought to be more attractive $(M=4.02, S D=0.37)$ than feminine characteristics $(M=3.60, S D=0.44)$, and an uninteresting marginal main effect of manager gender, $F(1$, $3027)=2.96, p=.086$ that was qualified by the expected interaction effect, $F(1,3027)=13.86, \quad p<.001$. To interpret this interaction effect we performed two separate ANOVAs, for masculine and feminine characteristics. This showed that, as expected, those with a male and those with a female manager did differ in their preference for feminine characteristics. Those with a male manager found feminine characteristics less attractive $(M=3.59$, $S D=0.44)$, than those with a female manager did $(M=3.66, \mathrm{~S} D=0.41), F(1,3027)=11.36, p<.001$. As also expected, gender of manager did not affect the preference for Masculine characteristics, because those with a male manager $(M=4.03, S D=0.37)$ and a female manager $(M=4.01, S D=0.38)$ did not differ in their preference for masculine characteristics, $F(1,3027)=0.92$, $p=.34$. Hypothesis 3 is therefore confirmed.

Next, we checked whether this effect of having a female manager also converted in an increased preference for female leaders. These analyses are shown in Table 1 (bottom). Using the same algorithm as in the previous section, we again found a strong preference for male leaders among respondents with a male manager, difference $=-20.4 \%$, $t(2582)=-19.38, p<.001$. Most interestingly, this preference for male leaders was absent among those with a female manager, difference $=-2.7 \%, t(445)=-1.04$, $p=.30$. A $t$ test comparing this preference for male managers between those with a male and those with a female manager showed that this difference is significant, $t(3027)=-6.44, p<.001$. Hypothesis 4 is therefore confirmed.

\section{Management Gender Ratio}

To test Hypotheses 5 and 6, we performed a regression analysis with percentage of female managers as the independent and preference for feminine characteristics as the dependent variable. Results showed that the presence of female managers in the organization had the expected positive effect, $B=.03, \quad S E=.01, \quad t(2931)=2.57$, $p=.010$. A second regression analysis on the effect of the percentage of female managers on the preference for masculine characteristics showed the expected null-effect, $B=-.001, \quad S E=.01, \quad t(2931)=-0.15, \quad p=.88$. Hypothesis 5 was therefore confirmed. Finally, a third regression analysis with percentage of female managers as independent and preference for female versus male managers as dependent variable, also showed the expected positive effect, $B=.03, \quad S E=.01, \quad t(2931)=2.56$, $p=.010$. Hypothesis 6 was therefore confirmed.

\section{The Relative Importance of the Three Factors}

In order to determine the relative contribution of the suggested predictors, we performed a mixed regression analysis with respondent's gender $(0=$ male, $1=$ female $)$, manager gender $(0=$ male, $1=$ female $)$, and gender ratio of management (studentized) as predictor variables. First, we analyzed the data with preference for feminine leadership characteristics as the dependent variable. We found that respondent's gender, $B=.05, S E=.02, t(2929)=$ $2.60, p=.009$, and gender of the manager, $B=.05$, $S E=.02, t(2929)=1.93, p=.054$, were significant predictors, but gender ratio in management was not, $B=.01$, $S E=.01, t(2929)=1.22, p=.22$. In the second step, we also added the two-way and three-way interaction effects between the predictors. This showed only an interaction effect between respondent's gender and gender ratio, $B=-.07, S E=.03, t(2925)=-2.56, p=.010$. Plotting of this interaction effect (see Fig. 1) showed that the difference between male and female respondents on their liking of feminine leader characteristics is the strongest, if the ratio of women in management is low. Also, it shows that the percentage of female managers has a relatively strong effect on men (Pearson $r=.065, p=.004$ ), but no effect on women $(r=.001, p=.97)$.

Second, we analyzed the effect of the three predictors on the preference for a female versus male leader. Here, we found that manager's gender was clearly the strongest predictor, $B=.15, S E=.03, t(2929)=5.02, p<.001$, 


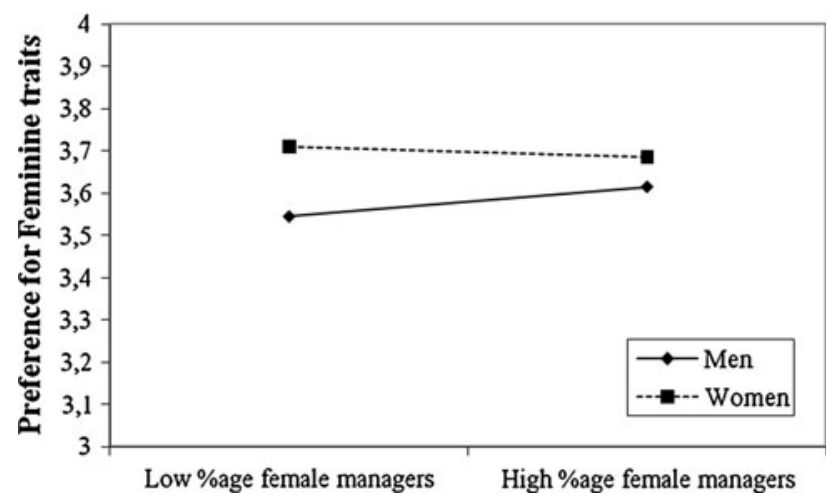

Fig. 1 Preference for feminine traits among men and women, in organizations with low and high percentage female managers. Lines show plotted simple slopes following Aiken and West (1991) and Dawson and Richter (2006)

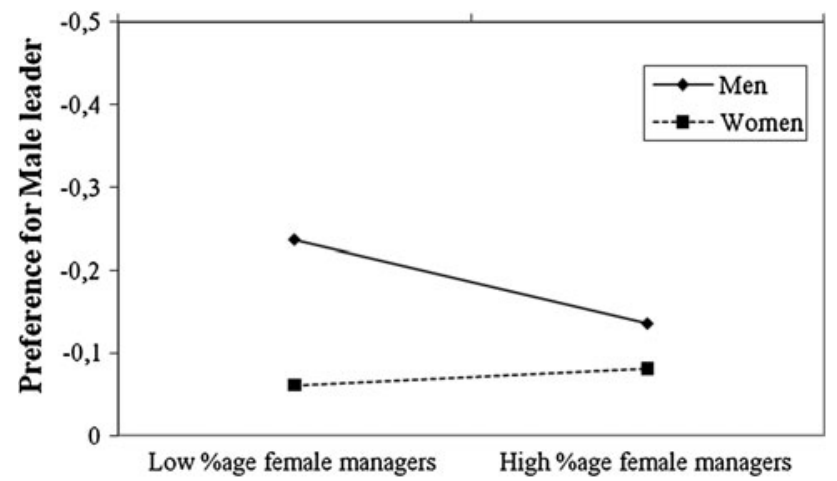

Fig. 2 Preference for a male over a female manager, among men and women, in organizations with low and high percentage female managers. Theoretical scores are between -1 (all respondents prefer a male leader) and +1 (all prefer a female leader). Positive scores indicate a preference for women, negative scores indicate a preference for men. Note that for ease of interpretation, the $Y$-axis is reversed; vertically higher (i.e., more negative) scores depict stronger preference for men

while respondent's gender, $B=.01, \quad S E=.02$, $t(2929)=0.38, p=.70$, and gender ratio in management, $B=.01, S E=.01, t(2929)=0.54, p=.59$ were not. In a second step, we added the two-way and three-way interaction effects. Here, we also found the same interaction effect of own gender and gender ratio, $B=-.09$, $S E=.04, t(2925)=-2.40, p=.016$. Plotting of this interaction effect (Fig. 2) again showed that the difference between male and female respondents on their preference for a male versus female leader is the strongest if the ratio of women in management is low. It shows again that increasing the percentage of female managers especially attenuates men's strong preference for male leaders $(r=$ $-.07, p=.001)$ but does not affect women's preferences $(r=-.01, p=.85)$.

\section{Conclusions and Discussion}

The purpose of this study was to gain insight into factors related to managerial stereotypes. Our results clearly show that all three factors contribute to an increased preference for feminine leadership characteristics without affecting the preference for masculine leadership characteristics (Hypotheses 1, 3, and 5). This supports the claim of Eagly and Sczesny (2009) that the stereotype of a manager shifts in a feminine direction. However, the preference for masculine characteristics does still exist. Therefore, we argue that female employees, employees with female managers, and employees working in organizations with high percentage of women in management, have a stronger androgynous stereotype of the ideal leader (Cheng 2005; Powell et al. 2002).

Moreover, the same factors also affect the general preference for women in leadership. In our dataset we still find a preference for male leaders, which is consistent with the findings of Powell et al. (2002). But if an employee is female, if an employee has a female manager, or if the percentage of female managers in the management gender ratio is high, this preference for male managers is significantly less strong.

With respect to the relative importance of the three independent variables, our hypothesis was also confirmed. The analyses revealed that the preference for feminine leadership characteristics was best predicted by proximal variables: the gender of the employee and the gender of the manager. Regarding the preference for a female manager, the gender of the manager was the strongest predictor. This means that proximal variables are much stronger predictors than the more distal variable, management gender ratio.

For the two dependent variables, we found the same significant interaction between the employees' gender and the management gender ratio: the difference between male and female respondents on their preference for masculine versus feminine characteristics and for a male versus a female leader is the strongest if the ratio of women in management is low. So, men are especially likely to dislike female leadership traits and prefer male leaders in organizations where female managers are rare. Or stated more positively: male employees start to appreciate feminine traits in leaders and female leaders more when they are represented members in the work environment.

Our findings have several implications for role congruity theory, the Contact Hypothesis, and tokenism theory. First, a managerial stereotype that is combining both masculine and feminine characteristics will affect the presumed role incongruity for female managers. It could be argued that they will suffer less from role incongruity, since the gender stereotype of a "good female" is becoming less contradictory to this "new" managerial stereotype. So this may 
lead to a situation in which role incongruity is simply becoming less significant and thereby be fading away as a barrier for female managers.

Second, our results clearly stress the importance of proximal variables (own gender and gender of manager) being stronger predictors than the more distal variable, management gender ratio. This reconfirms the Contact Hypothesis (Allport 1954; Sherif 1966). Although the number of female managers in the organization seems to make a difference: direct exposure to a female manager is related to having a more androgynous managerial stereotype. Also, the interaction-effect matches with the Contact Hypothesis; people like members of other groups more if they have more contact with them.

With respect to this interaction-effect, we can also add to tokenism theory (Kanter 1977; Ely 1995; King et al. 2010). Male employees especially dislike female leadership traits in organizations where female managers are tokens. This suggests that managerial stereotypes are especially strong for men as long as female managers are tokens.

Limitations of this Study and Recommendations for Future Research

Our study has some limitations that should be addressed. A first concern is the degree to which our results can be generalized given the nature of our sample. Most of the respondents were aged between 25 and 45 and highly educated, reflecting the target audience of the weekly publication. It is possible that the findings would have been different with a different sample. Lortie-Lussier and Rinfret (2002) noted that age and educational background seemed to be a factor in a person's attitudes toward female managers. Although our selected sample was an important sample, since these are individuals who are making up today's professional workforce and will be the leaders of the future, we would advise to replicate our study in a different cultural context, with a lower-educated and older sample.

Moreover, using an electronic questionnaire may have drawbacks. Denscombe (2006) argued that electronic questionnaires are as reliable as paper-based versions. However, in this case where such a survey is executed among subscribers to weekly publication, it is even more crucial to assess whether the sample is representative of the subscribers as a whole. Intermediair frequently performs studies involving its subscribers in this way, and the background and biographical data in our study were similar to their previous studies.

Concerning the use of the Gallup poll, we used this instrument slightly differently, because we gave respondents the explicit option of "no preference," when asking them their preference for a male or female manager. The original Gallup poll gave no such option: respondents could only think of this option themselves. Results from recent poll studies (see Eagly 2007) show that the most popular response in 2006 was "no preference" or "it doesn't matter" (43\%), so our findings of the high percentage of 70 are not that uncommon. An explanation for our results on the fact that most respondents indicated to have "no preference" might be the cultural context of our sample. In Dutch society, which tends to be egalitarian, respondents may feel that indicating a preference either way would reflect prejudice, which would be seen as inappropriate or politically incorrect.

A factor we did not consider was whether the respondents had had a female manager in the past-we asked only about their current manager. Other studies (Duehr and Bono 2006; Lortie-Lussier and Rinfret 2002) have suggested that earlier experiences of having a female supervisor can be a factor in one's current views and attitudes. Also, it would be interesting to study whether these experiences were positive or negative.

Another suggestion of Dennis and Kunkel (2004) is that one should assess the employees' gender identity, and not simply record their gender. Further, it is possible that the length of time one has reported to one's current manager could influence views on managerial stereotypes. These are all areas concerning the background of the employees which we failed to address due to lack of appropriate information, and we would suggest that these factors are included in future studies.

Finally, the cross-sectional nature of this study imposes some limitations. We are not able to determine the direction of the relationships: it may be that employees with a less gender-stereotypical view of leadership actively seek female managers. However, at the time of the survey, there was relatively high unemployment in the Netherlands and we would suspect that most people would not have had the luxury of picking and choosing among a pool of managers. For future studies, and given the now tighter labor market, it would be interesting to study the longitudinal effects of male and female leaders and changing stereotypes. It would also be interesting to study employees longitudinally, i.e., to examine employees who have a male manager at Time 1 and a female manager at Time 2 (and vice versa) to see if their preferences change accordingly.

\section{Implications for Organizational Practice}

The traditional managerial stereotypes had consequences that may include a bias against selecting and promoting women to management positions. Our results suggest that increasing the proportion of female managers is an effective way to influence these stereotypes. This is in line with 
the argument of Eagly and Carli (2003a), who suggested that organizations can capture the symbols of progressive social change and modernity by appointing women to key positions. However, our results also imply that only appointing women to these positions will not be enough: having actual experience working for a female manager leads employees to describe their ideal manager as androgynous rather than masculine.

We realize that changing managerial stereotypes is a long-term endeavor (Roberson and Kulik 2007). However, appointing more female managers, and avoiding tokenism, is a strategy that can contribute to the diminishment of stereotypes in the long run. Our results especially point into the direction of proximal variables as much stronger predictors than more distal variables. This would argue for appointing women at different levels and departments throughout the organization, so female leaders are close to employees in several positions. It also seems sensible not to concentrate the appointment of female managers in one or two places. The latter might easily lead to subtyping, meaning that minorities-although entering the domain of the majority - are being subtyped into a different category (Richards and Hewstone 2001; Weber and Crocker 1983). For example, appointing females as managers in the HR-department might easily lead to the perception that females are only suitable as HR-managers, thus not changing the general type of the ideal manager.

Finally, we admit that increasing the number of women in organizations is not the only way to improve the image of female management. A short-term strategy that does not involve changing the demographic make-up of the organization is creating awareness of role models who contradict the stereotype (Roberson and Kulik 2007). This can be achieved by encouraging managers and employees to participate in mentoring programs, or join professional associations and network groups (see Friedman and Holtom 2002). Also, organizations and managers can try to reduce the impact of stereotypes. Roberson and Kulik (2007) suggest that this starts by acknowledging the fact that stereotypes do exist, and that discussing stereotypes can be an effective first step in reducing their impact. To conclude, there are several ways to improve the position of women in organizations. Most likely, it is wisest to use all simultaneously.

Acknowledgments The authors wish to thank Intermediair for the opportunity to publish the results from data obtained from their subscribers. The authors are grateful to Alice Eagly, Peter van der Meer and Jennifer Jordan for their constructive feedback on this article.

Open Access This article is distributed under the terms of the Creative Commons Attribution Noncommercial License which permits any noncommercial use, distribution, and reproduction in any medium, provided the original author(s) and source are credited.

\section{References}

Aiken, L. S., \& West, S. G. (1991). Multiple regression: Testing and interpreting interactions. Newbury Park, London: Sage.

Allport, G. (1954). The nature of prejudice. Reading, MA: AddisonWesley.

Amir, Y. (1969). Contact hypothesis in ethnic relations. Psychological Bulletin, 71, 319-342.

Asuncion, A. G., \& Mackie, D. M. (1996). Undermining social stereotypes: Impact of affect-relevant and behavior-relevant information. Basic and Applied Social Psychology, 18, 367-386.

Atwater, L. E., Brett, J. F., Waldman, D., DiMare, L., \& Hayden, M. V. (2004). Men's and women's perceptions of the gender typing of management subroles. Sex Roles, 50, 191-199.

Ayman, R., Korabik, K., \& Morris, S. (2009). Is transformational leadership always perceived as effective? Male subordinates' devaluation of female transformational leaders. Journal of Applied Social Psychology, 39, 852-879.

Ayman-Nolley, S., \& Ayman, R. (2005). Children's implicit theory of leadership. In B. Scheins \& J. R. Meindl (Eds.), Implicit leadership theories - essays and explorations (pp. 227-274). Greenwich, CT: Information Age Publishing.

Bem, S. L. (1981). Bem Sex-Role Inventory: Professional manual. Palo Alto, CA: Consulting Psychologists Press.

Billing, Y. D., \& Alvesson, M. (2000). Questioning the notion of feminine leadership: A critical perspective on the gender labelling of leadership. Gender, Work and Organization, 7, 144-157.

Brescoll, V. L., Dawson, E., \& Uhlmann, E. L. (2010). Hard-won and easily lost: The fragile status of counter-stereotypical leaders. Psychological Science, 21, 1640-1642.

Brenner, O. C., Tomkiewicz, J., \& Schein, V. E. (1989). The relationship between sex-role stereotypes and requisite management characteristics revisited. Academy of Management Journal, 32, 662-669.

Brewer, M. B., \& Miller, N. (1988). Contact and cooperation: When do they work? In P. Katz \& D. Taylor (Eds.), Eliminating racism: Means and controversies (pp. 315-326). New York: Plenum.

Byrne, D. (1971). The attraction paradigm. New York: Academic Press.

Campbell, T., Gillaspy, J. A., Jr., \& Thompson, B. (1997). The factor structure of the Bem sex-role inventory (BSRI): Confirmatory analysis of long and short forms. Educational and Psychological Measurement, 57, 118-124.

Cheng, C. (2005). Processes underlying gender-role flexibility: Do androgynous individuals know more or know how to cope? Journal of Personality, 73, 645-673.

Cooley, C. H. (1909). Social organization: A study of the larger mind. New York: Scribner's Sons.

Dawson, J. F., \& Richter, A. W. (2006). Probing three-way interactions in moderated multiple regression: Development and application of a slope difference test. Journal of Applied Psychology, 91, 917-926.

Deal, J. J., \& Stevenson, M. A. (1998). Perceptions of Female and Male Managers in the 1990s: Plus ça change. Sex Roles, 38, 287-300.

Dennis, M. R., \& Kunkel, A. D. (2004). Perceptions of men, women and CEOs: the effects of gender identity. Social Behavior and Personality, 32, 155-171.

Denscombe, M. (2006). Web-based questionnaires and the mode effect: An evaluation based on completion rates and data contents of near-identical questionnaires delivered in different modes. Social Science Computer Review, 24, 246-254.

Diekman, A. B., \& Eagly, A. H. (2000). Stereotypes as dynamic constructs: Women and men of the past, present, and future. Personality and Social Psychology Bulletin, 26, 1171-1188. 
Diekman, A. B., Eagly, A. H., Mladinic, A., \& Ferreira, M. C. (2005). Dynamic stereotypes about women and men in Latin America and the United States. Journal of Cross-Cultural Psychology, 36, 209-226.

Diekman, A. B., \& Goodfriend, W. (2006). Rolling with the changes: A role congruity perspective on gender norms. Psychology of Women Quarterly, 30, 369-383.

Diekman, A. B., Goodfriend, W., \& Goodwin, S. (2004). Dynamic stereotypes of power: Perceived change and stability in gender hierarchies. Sex Roles, 50, 201-215.

Duehr, E. E., \& Bono, J. E. (2006). Men, women and managers: Are stereotypes finally changing? Personnel Psychology, 59, $815-846$

Eagly, A. H. (1987). Sex differences in social behavior: A social-role interpretation. Hillsdale, NJ: Erlbaum.

Eagly, A. H. (2007). Female leadership advantage and disadvantage: Resolving the contradictions. Psychology of Women Quarterly, $31,1-12$.

Eagly, A. H., \& Carli, L. L. (2003a). The female leadership advantage: An evaluation of the evidence. The Leadership Quarterly, 14, 807-834.

Eagly, A. H., \& Carli, L. L. (2003b). Finding gender advantage and disadvantage: Systematic research integration is the solution. The Leadership Quarterly, 14, 851-859.

Eagly, A. H., \& Carli, L. L. (2007). Through the labyrinth: The truth about how women become leaders. Boston: Harvard Business School Press.

Eagly, A. H., \& Karau, S. J. (2002). Role congruity of prejudice toward female leaders. Psychological Review, 109, 573-598.

Eagly, A. H., Makhijani, M. G., \& Klonsky, B. G. (1992). Gender and the evaluation of leaders: A meta-analysis. Psychological Bulletin, 111, 3-22.

Eagly, A. H., \& Sczesny, S. (2009). Stereotypes about women, men, and leaders: Have times changed? In M. Barreto, M. K. Ryan, \& M. T. Schmitt (Eds.), The glass ceiling in the 21st century: Understanding barriers to gender equality (pp. 21-47). Washington, DC: American Psychological Association.

Eagly, A. H., Wood, W., \& Diekman, A. H. (2000). Social role theory of sex differences and similarities: A current appraisal. In T. Eckes \& H. M. Trautner (Eds.), The developmental social psychology of gender (pp. 123-174). Mahwah, NJ: Erlbaum.

Ely, R. J. (1995). The power in demography: Women's social constructions of gender identity at work. Academy of Management Journal, 38, 589-634.

European Board Women Monitor. (2004). The first EWPN European Board Women Monitor. European Professional's Women Network. www.EuropeanPWN.net.

Friedman, R. A., \& Holtom, B. (2002). The effects of network groups on minority employee turnover intentions. Human Resource Management, 41, 405-421.

Heilman, M. E., Block, C. J., \& Martell, R. F. (1995). Sex stereotypes: Do they influence perception of managers? Journal of Social Behavior and Personality, 10, 237-252.

Hughes, F. N., \& Seta, C. E. (2003). Gender stereotypes: Children's perceptions of future compensatory behavior following violations of gender roles. Sex Roles, 49, 685-691.

Jackson, L. A., \& Sullivan, L. A. (1988). Age stereotype disconfirming information and evaluations of old people. Journal of Social Psychology, 128, 721-729.

Johnson, S. K., Murphy, S. E., Zewdie, S., \& Reichard, R. J. (2008). The strong, sensitive type: Effects of gender stereotypes and leadership prototypes on the evaluation of male and female leaders. Organizational Behavior and Human Decision Processes, 106, $39-60$.

Jones, J. M. (1997). Prejudice and racism. New York: McGraw-Hill.
Kanter, R. M. (1977). Men and women of the Corporation. New York: Basic Books.

King, E. B., Hebl, M. R., George, J. M., \& Matusik, S. F. (2010). Understanding tokenism: Antecedents and consequences of a psychological climate of gender inequity. Journal of Management, 36, 482-510.

Liden, R. C., Sparrowe, R. T., \& Wayne, S. J. (1997). Leader-member exchange theory: The past and potential for the future. Research in Personnel and Human Resources Management, 15, 47-119.

Lortie-Lussier, M., \& Rinfret, N. (2002). The proportion of women managers: Where is the critical mass? Journal of Applied Social Psychology, 32, 1974-1991.

Lyness, K. S., \& Heilman, M. E. (2006). When fit is fundamental: performance evaluations and promotions of upper-level female and male managers. Journal of Applied Psychology, 91, 777-785.

McColl-Kennedy, J. R., \& Anderson, R. D. (2005). Subordinatemanager gender combination and perceived leadership style influence on emotions, self-esteem and organizational commitment. Journal of Business Research, 58, 115-125.

Mead, G. H. (1962). Mind, self, and society from the perspective of a social behaviorist. New York: Schocken Books.

Pettigrew, T. F. (1997). Generalized intergroup contact effects on prejudice. Personality and Social Psychology Bulletin, 23, 173-185.

Powell, G. N. (1993). Women and men in management (2nd ed.). Newbury Park, CA: Sage.

Powell, G. N., \& Butterfield, D. A. (1979). The "good" manager: Masculine or androgynous? Academy of Management Journal, 22, 395-403.

Powell, G. N., \& Butterfield, D. A. (1989). The "good" manager: Did androgyny fare better in the 1980s? Group and Organization Studies, 14, 216-233.

Powell, G. N., Butterfield, D. A., \& Parent, J. D. (2002). Gender and managerial stereotypes: Have the times changed? Journal of Management, 28, 177-193.

Richards, Z., \& Hewstone, M. (2001). Subtyping and subgrouping: Processes for the prevention and promotion of stereotype change. Personality and Social Psychology Review, 5, 52-73.

Roberson, L., \& Kulik, C. T. (2007). Stereotype threat at work. Academy of Management Perspectives, 21, 24-40.

Rothbart, M. (1981). Memory processes and social beliefs. In D. L. Hamilton (Ed.), Cognitive processes in stereotyping and intergroup behavior (pp. 145-181). Hillsdale: Erlbaum.

Rothbart, M., \& John, O. P. (1985). Social categorization and behavioral episodes: A cognitive analysis of the effects of intergroup contact. Journal of Social Issues, 41, 81-104.

Ryan, M. K., \& Haslam, S. A. (2007). The glass cliff: Exploring the dynamics surrounding the appointment of women to precarious leadership positions. Academy of Management Review, 32, 549-572.

Sackett, P. R., DuBois, C. L. Z., \& Noe, A. W. (1991). Tokenism in performance evaluation: The effects of work group representation on male-female and White-Black differences in performance ratings. Journal of Applied Psychology, 82, 342-359.

Schein, V. E. (1973). The relationship between sex role stereotypes and requisite management characteristics. Journal of Applied Psychology, 57, 95-100.

Schein, V. E. (1975). Relationships between sex role stereotypes and requisite management characteristics among female managers. Journal of Applied Psychology, 60, 340-344.

Schein, V. E. (2001). A global look at psychological barriers to women's progress in management. Journal of Social Issues, 57, $675-688$.

Sczesny, S. (2003). A closer look beneath the surface: Various facets of the think-manager-think-male stereotype. Sex Roles, 49, 353-363. 
Sczesny, S., Bosak, J., Ness, J., \& Schyns, B. (2004). Gender stereotypes and the attribution of leadership traits: A crosscultural comparison. Sex Roles, 51, 631-645.

Sealy, R., Vinnicombe, S., \& Doldor, E. (2009). Female FTSE Index and report 2009. Bedford: Cranfield University.

Sherif, M. (1966). In common predicament: Social psychology of intergroup conflict and cooperation. Boston: Houghton-Mifflin.

Sherif, M., Harvey, O. J., White, B. J., Hood, W. R., \& Sherif, C. W. (1961). Intergroup cooperation and competition: The robber's cave experiment. Norman: University of Oklahoma Book Exchange.

Simmons, W. W. (2001). When it comes to choosing a boss, Americans still prefer men. From the Gallup Poll News Service Web site: http://www.gallup.com. January 11.

Stuhlmacher, A. F., \& Poitras, J. (2010). Gender and job role congruence: A field study of trust in labor mediators. Sex Roles, 63, 489-499.

Swan, S., \& Wyer, R. S., Jr. (1997). Gender stereotypes and social identity: How being in the minority affects judgment of self and others. Personality and Social Psychology Bulletin, 23, 1265-1276.

Tajfel, H., \& Turner, J. C. (1986). The social identity theory of intergroup behavior. In S. Worchel \& L. W. Austin (Eds.), Psychology of intergroup relations (pp. 33-48). Chicago: Nelson-Hall.
Tausch, N., \& Hewstone, M. (2010). Social dominance orientation attenuates stereotype change in the face of disconfirming information. Social Psychology, 41, 169-176.

Vecchio, R. P., \& Boatwright, K. J. (2002). Preferences for idealized styles of supervision. The Leadership Quarterly, 13, 327-342.

Voci, A., Hewstone, M., Crisp, R. J., \& Rubin, M. (2008). Majority, minority, and parity: Effects of gender and group size on perceived group variability. Social Psychology Quarterly, 71, 114-142.

Weber, R., \& Crocker, J. (1983). Cognitive processes in the revision of stereotypic beliefs. Journal of Personality and Social Psychology, 45, 961-977.

Wellington, S., Kropf, M. B., \& Gerkovic, P. R. (2003). What's holding women back? Harvard Business Review, 81, 18-19.

Willemsen, T. M. (2002). Gender typing of the successful managera stereotype reconsidered. Sex Roles, 46, 385-391.

Yoder, J. D., \& Schleicher, T. L. (1996). Undergraduates regard derivation from occupational gender stereotypes as costly for women. Sex Roles, 34, 171-188.

Young, J. L., \& James, E. (2001). Token majority: The work attitudes of male flight attendants. Sex Roles, 34, 171-188.

Yukl, G. (2002). Leadership in organizations (5th ed.). Upper Saddle River, NJ: Prentice-Hall. 